\title{
PRODUCTION AND EVALUATION OF PARTIALLY AIR DEHYDRATED AND EDIBLE COATED MANGO SLICES
}

\author{
MOSTAFA T. M. ASSOUS \\ Food Technology Research Institute, ARC, Giza, Egypt. \\ (Manuscript received 10 March 2014)
}

\begin{abstract}
The present study was carried out to investigate the effects of osmosis, partially dehydrating and edible coating with chitosan on physical, chemical, microbiological and sensory evaluation of mango slices after processing and during storage at controlled room temperature $\left(25 \pm 3{ }^{\circ} \mathrm{C}\right)$. Mango slices (keitt cultivar) were osmotic dehydrated by immersing in sucrose solution $60 \%$ till moisture content reached about $55 \%\left(\mathrm{~T}_{1}\right)$, and then partially air dehydrated to moisture contents $40 \%\left(T_{2}\right), 30 \%\left(T_{3}\right)$ and $20 \%\left(T_{4}\right.$ and $\left.T_{5}\right)$. Treatments $T_{1}, T_{2}, T_{3}$ and $T_{4}$ were dipped into coating forming chitosan solution, while $T_{5}$ was a control. The results showed that weight loss, moisture content and osmotic dehydration ratio were $41.5 \%$, $55.13 \%$ and $1.70: 1$, respectively, after osmosis. The results indicated that moisture content of osmotic dehydrated, then partially air dehydrated coated mango slices $\left(T_{2}, T_{3}\right.$ and $\left.T_{4}\right)$ were 41.11, 29.52 and 19.67\%, respectively. Results indicated that osmotic dehydrated mango slices then partially air dehydrated and coated were maintained physical and chemical properties during storage at controlled room temperature compared with control treatment. Statistical analysis of sensory evaluation for coated partially air dehydrated mango slices $\left(T_{2}\right.$ and $\left.T_{3}\right)$ showed an acceptable scores sensory evaluation for 6 month at $25 \pm 3{ }^{\circ} \mathrm{C}$, while treatment $\left(T_{1}\right)$ was an acceptable scores sensory evaluation for 2 months from storage. Edible coating with chitosan- methyl cellulose of osmotic dehydrated mango slices or osmotic dehydrated then partially air dehydrated was not accompanied by a remarkable increase in microbial load during storage. Keywords; osmosis, mango, dehydration, edible, chitosan, storage

Email; Assous2010@yahoo.com
\end{abstract}

\section{INTRODUCTION}

Mango (Mangifera indica L.) is one of the oldest widely cultivated fruits. It belongs to the family Anacardiaceae. It is the most preferring tropical fruit around the world espially in Egypt due to its attractive color, good flavor, taste, and its high content of bioactive compounds such as ascorbic acid, $\beta$ carotene and phenolic compounds. All these bioactive compounds are good antioxidants and their daily intake in the diet has been related to prevention of degenerative processes such as cardiovascular diseases and cancer (Liu, 2003).

According to the (FAO, 2013) the annual production of mango fruit in Egypt was estimated to be 598,084 tons produced from a total area of 284,036 feddans in 2011 .

Fresh mangos are extremely perishable and cannot be marketed or exported as fresh produce over long periods resulting limit availability. Thus, mangos are 
preserved as puree, nectars, syrups, blended juices, dehydrated slices or canned as slices or cubs to meet demand of the market thought in all years.

Drying prolonged exposure to elevated drying temperatures, resulted in substantial degradation in quality attributes, such as color, nutrients, flavor, texture, severe shrinkage, reduction in bulk density and rehydration capacity, damage to sensory characteristics and solutes migration from the interior of the food to the surface( Maskan ,2001).

Osmotic dehydration is a useful technique that involves product immersion in sugar solutions leading to water loss and sugar gain in the fruit. The osmotic process has received considerable attention as a pre-drying treatment so as to reduce energy consumption and improve food quality (Giraldo et al, 2003).

There has been a growing interest in recent times to develop materials with filmforming capacity and having antimicrobial properties which help improve food safety and shelf life. Edible films and coatings offer extra advantages such as edibility, appearance, barrier to gasses properties, non-toxicity, non-polluting besides its low cost. Edible coatings are gaining importance as an alternative to reduce the deterioration caused by minimal processing of fresh fruits. Edible films and coatings have a potential to extend the shelf-life and quality of foods by preventing changes in aroma, taste, texture and appearance ( Robles-Sánchez et al, 2013).

Chitosan is a natural biopolymer derived from chitin that is found in crustacean shells, fungi cell walls and other biological materials. Also, it can be extracted from the wastes of the frozen sea food industry as a by-product. There is a considerable potential to use this by-product in many applications. Chitosan is a polymer composed of $\beta$-(1, 4)-2-deoxy-2-amino-D-glucopyranose units (Kim et al, 2006). Chitosan has good flow and film forming characteristics and is nontoxic, biodegradable, biofunctional and an important antimicrobial properties (Pranoto et al, 2005).

The use of partially dehydrated fruit, obtained by osmotic dehydration and vacuum impregnation processes, and the application of an edible coating on it, could enhance the quality of these kinds of products (Talens et al, 2012).

The objective of this study was to evaluate the quality parameters of mango slices treated with osmotic dehydration, partially air dehydration and edible coating with chtiosan - methyl cellulose film and storage at controlled room temperature $\left(25 \pm 3^{\circ} \mathrm{C}\right)$.

\section{MATERIALS AND METHODS}

\section{Materials}

Mango fruit (Keitt cultivar) at the firm ripe stage was obtained from the Horticultural Research Institute, Agriculture Research Center, Giza, Egypt in Septamper; 2012.Sucrose was obtained from Sugar and Integrated Industries Co., Egypt. Citric acid, potassium sorbate and ascorbic acid were obtained from El- 
gamhoria Co., Egypt. Chitosan from crab shells was obtained from Roth Co., Germany. Methyl cellulose was purchased from(S D Fine-Chem Limited), India. Nutrient and malt agar for microbiological evaluation were obtained from Biolife Co., Italy. Packaging material of the three layers (polyethylene, polyester and aluminum foils) was provided from Nile Co., for Printing and Packaging, 10th of Ramadan City, Egypt.

\section{Processing methods}

\section{Preparation of mango slices}

Mango fruits were washed, peeled, cut into slices $(0.8-1 \mathrm{~cm}$, thick) and were exposed to steam for $2 \mathrm{~min}$. then cooled with tap water.

\section{Preparation of osmotic solution}

Sucrose solution concentration at $60 \%$ was prepared; citric acid and potassium sorbate $0.2 \mathrm{w} / \mathrm{v}$ and $0.2 \mathrm{w} / \mathrm{v} \%$ respectively were added to solution.

\section{Preparation of coating-forming solution}

Chitosan solution was prepared according to Talens, et al, (2012) by dissolving chitosan $(1 \mathrm{~g})$ in $100 \mathrm{ml}$ distilled water acidified with $(1 \mathrm{ml})$ glacial acetic acid with continuous stirring at room temperature $\left(25 \pm 3^{\circ} \mathrm{C}\right)$ to complete dissolving. After, the complete dissolution of the chitosan, $2 \mathrm{~g}$ of methylcellulose and $0.1 \mathrm{~g}$ of ascorbic acid were added to chitosan solution, respectively. The $\mathrm{pH}$ of coating -forming solution was adjusted to 5.2 with $\mathrm{NaOH}$ after stirring using a rotor-stator homogenizer then filtrated to remove remaining small insoluble particles from solution. The resulting solution was used as chtiosan - methyl cellulose film coating.

\section{Osmotic dehydration}

Mango slices were immersed in osmotic solution at room temperature according to Assous (2004) using a mass ratio of fruit to the osmotic solution of $1: 3$ (wt: wt) till moisture content reached $\sim 55 \%$.

\section{Drying}

Osmotic dehydrated mango slices were partially air dehydrated in electric oven at $60 \pm 3^{\circ} \mathrm{C}$ till moisture percentage reached about 40,30 and $20 \%$.

\section{Coating of partially air dehydrated mango slices}

Osmotic dehydrated mango slices $\left(T_{1}\right)$, osmotic dehydrated mango slices and then partially air dehydrated in a convection oven to moisture contents about $40 \%\left(T_{2}\right)$, $30 \%\left(\mathrm{~T}_{3}\right)$ and $20 \%\left(\mathrm{~T}_{4}\right)$ were dipped into coating-forming solution for $2 \mathrm{~min}$. After edible coating application, mango sliced was dried by exposure to flowing air at room temperature to set a coat of the films on their surfaces. The osmotic dehydrated mango slices, then air dried to moisture content about $20 \%$ (T5) except dipping in coating solution was used as control (commercial sample).

Processing of osmotic dehydrated and partially air dehydrated, edible coated mango slices are illustrated in Fig. (1). 


\section{Analytical methods}

Fresh, partially air dehydrated and stored mango slices samples were subjected to the followingdeterminations as follows:

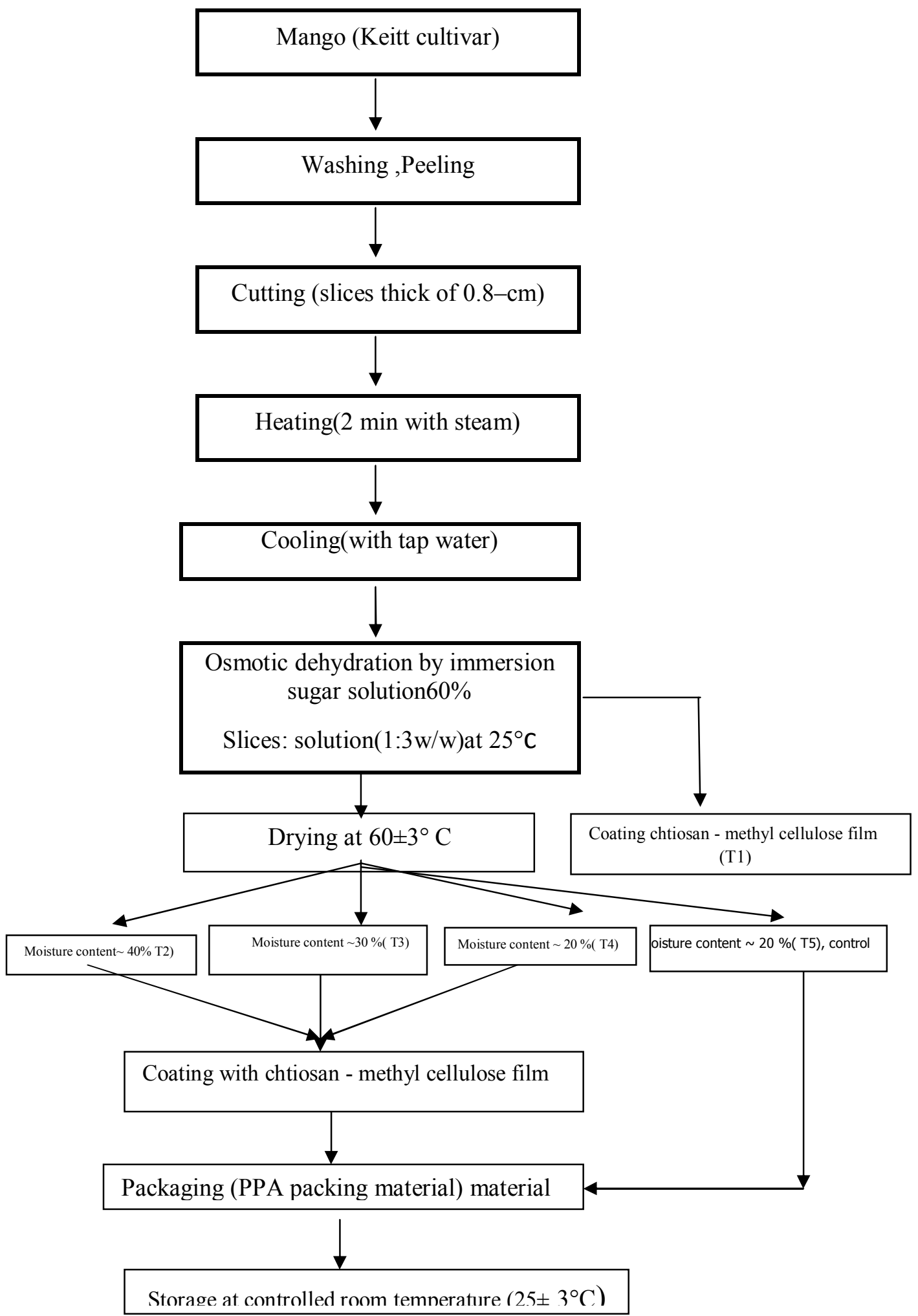

Fig. 1. Schematic representation of partially dehydrated, edible coated mango slices. 


\section{Packaging and storage}

Coated and control mango slices were packed in laminate sacs PPA packing material (polyethylene, polyester and aluminum foils, $15 \times 20 \mathrm{~cm}$ ) and stored at controlled room temperature $\left(25 \pm 3^{\circ} \mathrm{C}\right)$ for 6 months. Chemical, microbiological and sensory evaluations of the stored samples were carried out after 2, 4 and 6 months of storage.

Moisture, total soluble solids (T.S.S.), pH value, total titratable acidity, reducing, non- reducing and total sugars, crude fiber, ash, ascorbic acid and Total phenolic contents were determined according to the methods of A.O.A.C. (2005). The total carotenoids and non-enzymatic browning were determined according to the method of Ranganna (1977). Antioxidant activity of samples extracts was studied through the evaluation of the free radical-scavenging effect on the 1, 1-diphenyl-2-picrylhydrazyl (DPPH) radical. The results were expressed as percentage of inhibition of the DPPH radical. Percentage of inhibition of the DPPH radical was calculated according to Alothman et al, (2009) using the following equation:-

$\%$ inhibition of DPPH $=\frac{\text { (Abs control-Abs sample) }}{\text { Abs.control }} \times 100$

Where: Abs. control is the absorbance of DPPH solution without extracts, Abs. sample is the absorbance of DPPH with solution extracts. Shear force was used to determine firmness of fresh and partially air dehydrated $(4 \mathrm{~mm} \times 5 \mathrm{~mm})$ samples using testing machine model no. AIM 339 - 3 (Largo, Florida 33543, USA) equipped with AIM Desktop microcomputer (A 65 - 50 series) with $2 \mathrm{~mm}$ plunger. The results were reported as Newton (N) according to the method described by Djioua et al, (2009). Dehydration ratio was calculated for samples after air dehydration according to VanArsdel and Copley (1964) as follows: Dehydration ratio = Weight of samples before osmotic dehydration / weight of samples after osmotic dehydration

\section{Microbiological evaluation}

Total bacterial, yeast and mold counts were carried out for fresh, coated dried fruit slices and also throughout storage that extended for 6 months according to the methods outlined by Collins and Lyne (1976).

\section{Sensory evaluation}

Mango slices of the partially dried coated samples and also during storage were subjected to sensory evaluation test. Ten panelists evaluated the samples according to the numerical scoring test. The panelist evaluated each sample on a specific scale of 10 for, taste, color, texture and odor according to Raybaudi-Massilia et al, (2008).

\section{Statistical analysis}

The obtained data from sensory evaluation were subjected to analysis of variance (ANOVA) using SPSS software (SPSS, 1999). 


\section{RESULTS AND DISCUSSION}

\section{Physical and chemical properties of fresh mango fruit (Keitt cultivar).}

Results in Table (1) represent some physicochemical properties of fresh mango (Keitt cultivar). Moisture content at firm ripe stage was $80.48 \%$; it means that the total solids of keitt cultivar was $19.52 \%$ wher most solids are soluble solids and represent $89.65 \%$ of solids. Firmness of keitt mango was $3.4(\mathrm{~N})$ which considers the most suitable stage for osmotic dehydration. Result in Table (1) indicated that total sugars, crude fiber and ash were $16.28,0.86$ and $0.64 \mathrm{~g} / 100 \mathrm{~g}$ on fresh weight basis, respectively. Also, the data declare that keitt mango fruit was rich in antioxidant compounds (ascorbic acid, total carotenoides and phenolic compounds) which represent $41.42,6.14$ and $32.1 \mathrm{mg} / 100 \mathrm{~g}$ on fresh weight basis, respectively. These results are in agreement with those reported by Djioua, et al., (2009), Liu, et al., (2013) and Robles-Sanchez, et al., (2013).

Table 1. physical and chemical properties of fresh mango fruit (Keitt cultivar).

\begin{tabular}{|c|c|}
\hline Properties & Value \\
\hline Moisture & 80.48 \\
\hline T.S.S & 17.5 \\
\hline $\mathrm{pH}$ value & 6.06 \\
\hline Firmness $(\mathrm{N})$ & 3.4 \\
\hline Non-enzymatic-browning Abs.420nm) & 0.012 \\
\hline Total titratable acidity & 0.154 \\
\hline Total sugars & 16.28 \\
\hline Reducing sugars & 6.39 \\
\hline Non-reducing sugars & 9.89 \\
\hline Crude fiber & 0.86 \\
\hline $\mathrm{g} / 100 \mathrm{~g}$ & 0.64 \\
\hline Ascorbic acid & 41.42 \\
\hline Phenolic compounds & 32.1 \\
\hline Total carotenoids & 6.14 \\
\hline Antioxidant activity & 61.74 \\
\hline
\end{tabular}

\section{Effect of osmotic dehydration on physical and chemical properties of fresh cut mango fruit (keitt cultivar).}

Results in Table (2) show that the osmotic dehydration ratio was 1.70:1.It is meaning each $100 \mathrm{~g}$ of fresh mango slices become $58.5 \mathrm{~g}$ after osmotic dehydration and that was mainly due to loss of moisture and therefore the ratio of chemical compounds at least outwardly but increased quantitatively especially sugars. Also, 
firmness of mango slices decreased to1.5 $\mathrm{N}$ represented $44.11 \%$ of initial value (fresh slices).Moisture content of mango slices decreased from 80.48 to $55.13 \%$ after osmotic dehydration. It was explained that the osmotic process has received considerable attention as a pre-dehydration treatment so as to reduce energy consumption and improve food quality (Giraldo et al., 2003).

Results in Table (2) indicated that quantity of total sugar contents of osmotic dehydrated mango slices were high yielded $44.63 \%$ while, quantity of ascorbic acid and total phenols were reduced by about 25 and $20.03 \%$ of their initial value of the fresh mango slices. This decrement of ascorbic acid and total phenols contents in osmosis mango slices could be due to oxidation of those compounds during osmosis and solubility in osmotic solution. Also, in the same table, one can observe that quantity of total carotenoids and crude fiber were almost stable after osmotic dehydration; it may be due to that non-solubility of these compounds in osmotic solution and using mango slices at firm ripe stage. On the other hand ,the total caroteniods and fiber content nominal increased due to the decreasing of the moisture content of the fresh osmotic dehydrated slices. Antioxidant capacity has been used to evaluate the antioxidant potential status of tissue, which is a function of the type and amount of bioactive compounds present. Antioxidant activity of mango slices was reduced after osmotic treatment .It could be due to the reduction of antioxidant compounds such as ascorbic acid and total phenols (Robles-Sánchez et al., 2013).

\section{Effect of drying on physical and chemical properties of osmotic dehydrated mango slices.}

Results in Table (3) indicated that moisture content of partially air dehydrated mango slices was 41.11 of $\left(T_{2}\right), 29.53$ of $\left(T_{3}\right), 19.67$ of $\left(T_{4}\right)$ and $18.92 \%$ of $\left(T_{5}\right)$, respectively. Firmness of dehydrated mango slices was increased with reducing moisture content. Non-enzymatic browning was increased with increasing the reducing in moisture content of samples. It could be due to the reaction between sugars and amino acids especially with long time drying. Chemical compositions of partially air dehydrated mango slices were apparently increased with reduction moisture content. 
Table 2. Physical and chemical properties of osmotic dehydrated mango slices.

\begin{tabular}{|c|c|}
\hline Properties & $\left(T_{1}\right)$ \\
\hline Moisture & 55.13 \\
\hline T.S.S & 41.5 \\
\hline $\mathrm{pH}$ value & 4.85 \\
\hline Firmness $(\mathrm{N})$ & 1.5 \\
\hline Non-enzymatic-browning (Abs.420nm) & 0.072 \\
\hline Total titratable acidity & 0.264 \\
\hline Total sugars & 40.25 \\
\hline Reducing sugars & 18.11 \\
\hline Non-reducing sugars & 22.14 \\
\hline Crude fiber & 1.42 \\
\hline $\mathrm{g} / 100 \mathrm{~g}$ & 1.01 \\
\hline Ascorbic acid & 53.10 \\
\hline Phenolic compounds & 43.74 \\
\hline Total carotenoids & 9.95 \\
\hline Antioxidant activity & 48.32 \\
\hline Osmotic dehydration ratio & $1.70: 1$ \\
\hline Weight loss* & 41.5 \\
\hline
\end{tabular}

*Weight loss $\%=$ initial weight - Final weight /initial weight $\times 100$

Acidity and total sugars were slightly decreased on dry weight basis during drying. It could be due to the oxidation compounds and hydrolysis of non- reducing sugars to reducing sugars during dehydration especially in presence acids. Also, ascorbic acid and phenols were remarkable decreased with higher reducing moisture content on dry weight basis. It could be oxidation of ascorbic acid during long time of drying. Total carotenoids were slight decrease on dry weight basis after dehydration. It could be due to non-soluble pigments resistant to heat during dehydration of mango slices and short dehydration time. Pott et al., (2003) found that drying process resulted in partial degradation of carotene especially in the presence of oxygen and light. 


\section{Effect of edible coating and moisture content on physical properties of osmotic dehydrated and partially air dehydrated mango slices during storage.}

Moisture content, pH value, firmness and non-enzymatic browning of mango slices after coating and during storage at room temperature are represented in table (4).Moisture content of all coated mango slices recorded gradually increment parallel with storage time prolonged being

Table 3. Physical and chemical properties of osmotic dehydrated mango slices.

\begin{tabular}{|c|c|c|c|c|c|}
\hline \multicolumn{2}{|l|}{ Properties } & $\mathrm{T}_{2}$ & $\mathrm{~T}_{3}$ & $\mathrm{~T}_{4}$ & $\mathrm{~T}_{5}$ \\
\hline Moisture & $\%$ & 41.11 & 29.53 & 19.67 & 18.92 \\
\hline \multicolumn{2}{|l|}{$\mathrm{pH}$ value } & 4.88 & 4.90 & 4.95 & 4.98 \\
\hline \multicolumn{2}{|l|}{ Firmness $(\mathrm{N})$} & 2.36 & 3.21 & 4.19 & 4.52 \\
\hline \multicolumn{2}{|c|}{ Non-enzymatic-browning(Abs.420nm) } & 0.104 & 0.112 & 0.208 & 0.217 \\
\hline Total titratable acidity & $\mathrm{g} / 100 \mathrm{~g}$ & 0.338 & 0.367 & 0.404 & 0.398 \\
\hline Total sugars & $\mathrm{g} / 100 \mathrm{~g}$ & 52.60 & 62.73 & 71.27 & 71.84 \\
\hline Reducing sugars & $\mathrm{g} / 100 \mathrm{~g}$ & 24.63 & 29.60 & 34.43 & 34.83 \\
\hline Non-reducing sugars & $g / 100 \mathrm{~g}$ & 27.97 & 33.13 & 36.84 & 37.01 \\
\hline Ascorbic acid & $\mathrm{mg} / 100 \mathrm{~g}$ & 66.12 & 75.06 & 80.80 & 80.29 \\
\hline Phenolic compounds & $\mathrm{mg} / 100 \mathrm{~g}$ & 55.97 & 65.26 & 71.98 & 72.52 \\
\hline Total carotenoids & $\mathrm{mg} / 100 \mathrm{~g}$ & 12.79 & 15.00 & 16.73 & 16.87 \\
\hline Antioxidant activity & $\%$ & 44.11 & 40.21 & 36.10 & 35.62 \\
\hline
\end{tabular}

2.83-11.99\% compared to their values at zero time of storage. The increment of moisture content was more pronounced $21.30 \%$ for control sample (uncoated) of initial value. Meanwhile, non air dehydrated osmotic dehydrated sample $\left(T_{1}\right)$ has the lowest moisture content $2.83 \%$ of initial value. This may be due to the differences in initial moisture content, which led to sample have low moisture tend to absorb more water than of higher moisture content ones. The slight increase in moisture content of coated mango slices samples during storage; may be due to the barrier properties of chitosan to absorb moisture at relative high temperature (Olivas and BarbosaCanovas, 2005).Results in Table (4) indicated that firmness (N) was gradually decreased during storage. Also, it could be observed that, firmness of treatment $\left(T_{1}\right)$ recorded much firmness loss than that of other treatments. This could be attributed to their high moisture content level and /or the action of pectic enzymes (Rojas-Grau, et al., 2009). Browning intensity was slightly increased during storage. Polysaccharide coatings are good gas barriers delaying browning in all treatments (Chiumarelli et al., 2011).From results in table (4) one can notice that increasing moisture content of coated mango slices subsequently caused increment of non-enzymatic browning 
during storage. Also, this could be attributed to the higher degradation of ascorbic acid and carotenoid during storage (table, 6). Hymavathi and Khader (2005) indicated that higher correlation was seen in the case of $\beta$-carotene indicating that the nonenzymatic browning in the mango powders is mainly due to the lipid peroxidation rather than the ascorbic acid degradation. Chien et al., (2007) reported that the color of sliced mango fruit is importantly determines consumer acceptance, and although a chitosan coating did not change the original color of the fruit, it delayed browning.

Table 4. physical properties of osmotic dehydrated and partially air dehydrated coated mango slices during storage

\begin{tabular}{|c|c|c|c|c|c|c|}
\hline \multirow{2}{*}{ Properties } & \multirow{2}{*}{$\begin{array}{c}\text { Storage period } \\
\text { (month) }\end{array}$} & \multicolumn{5}{|c|}{ Osmotic dehydrated and partially air dehydrated mango slices } \\
\hline & & $\mathrm{T}_{1}$ & $\mathrm{~T}_{2}$ & $T_{3}$ & $\mathrm{~T}_{4}$ & $T_{5}$ \\
\hline \multirow{4}{*}{ Moisture \% } & Zero time & 55.13 & 41.11 & 29.53 & 19.67 & 18.92 \\
\hline & 2 & 55.75 & 42.31 & 30.62 & 20.87 & 20.44 \\
\hline & 4 & 56.00 & 42.76 & 31.80 & 21.55 & 21.81 \\
\hline & 6 & 56.69 & 43.05 & 32.13 & 22.03 & 22.95 \\
\hline \multirow{4}{*}{$\mathrm{pH}$ value } & Zero time & 4.85 & 4.88 & 4.90 & 4.95 & 4.98 \\
\hline & 2 & 4.90 & 4.95 & 4.98 & 5.01 & 5.01 \\
\hline & 4 & 4.95 & 5.00 & 5.01 & 5.06 & 5.15 \\
\hline & 6 & 5.06 & 5.06 & 5.05 & 5.10 & 5.21 \\
\hline \multirow{4}{*}{ Firmness (N) } & Zero time & 1.50 & 2.36 & 3.21 & 4.19 & 4.52 \\
\hline & 2 & 1.20 & 2.11 & 3.00 & 3.86 & 3.67 \\
\hline & 4 & 0.85 & 1.72 & 2.82 & 3.60 & 3.25 \\
\hline & 6 & 0.57 & 1.54 & 2.48 & 3.21 & 3.00 \\
\hline \multirow{4}{*}{$\begin{array}{l}\text { Non-enzymatic- } \\
\text { browning } \\
\text { (Abs.420nm) }\end{array}$} & Zero time & 0.072 & 0.104 & 0.112 & 0.208 & 0.217 \\
\hline & 2 & 0.157 & 0.155 & 0.187 & 0.250 & 0.283 \\
\hline & 4 & 0.309 & 0.193 & 0.231 & 0.261 & 0.301 \\
\hline & 6 & 0.351 & 0.245 & 0.275 & 0.294 & 0.329 \\
\hline
\end{tabular}

$\mathrm{T}_{1}$ : Osmotic dehydrated to about $55 \%$ moisture content, coated mango slices.

$\mathrm{T}_{2}$ : Osmotic dehydrated, partially air dehydrated to about 40\%moisture content, coated mango slices.

$\mathrm{T}_{3}$ : Osmotic dehydrated, partially air dehydrated to about $30 \%$ moisture content, coated mango slices. $\mathrm{T}_{3}$ : Osmotic dehydrated, partially air dehydrated to about 20\%moisture content, coated mango slices. $T_{5}$ : Osmotic dehydrated, partially air dehydrated to about 20\%moisture content without coating mango slices (control). 


\section{Effect of edible coating and moisture content on chemical characteristics of osmotic dehydrated and partially air dehydrated mango slices during storage.}

Results in table (5) illustrate that total acidity and total sugars of coated mango slice with osmotic and air dehydration were slightly lower than that

Table 5. Chemical properties of osmotic dehydrated and partially air dehydrated coated mango slices during storage

Means with a column showing the same letter are not significantly different $(p>0.5) . T_{1}$ : Osmotic

\begin{tabular}{|c|c|c|c|c|c|c|}
\hline \multirow[t]{2}{*}{ Properties } & \multirow{2}{*}{$\begin{array}{c}\text { Storage } \\
\text { period (month) }\end{array}$} & \multicolumn{5}{|c|}{ Osmotic dehydrated and partially air dehydrated mango slices } \\
\hline & & $\mathrm{T}_{1}$ & $\mathrm{~T}_{2}$ & $\mathrm{~T}_{3}$ & $\mathrm{~T}_{4}$ & T5 \\
\hline \multirow{4}{*}{$\begin{array}{l}\text { Total titratable } \\
\text { acidity as citric } \\
\text { acid } \\
\qquad \text { g/100g }\end{array}$} & Zero time & $\begin{array}{c}0.264 \\
\pm 0.01^{\mathrm{a}}\end{array}$ & $\begin{array}{c}0.338 \\
\pm 0.013^{\mathrm{a}}\end{array}$ & $\begin{array}{c}0.367 \\
\pm 0.013^{\mathrm{a}}\end{array}$ & $\begin{array}{c}0.404 \\
\pm 0.011^{\mathrm{a}}\end{array}$ & $\begin{array}{c}0.398 \\
\pm 0.005^{\mathrm{a}}\end{array}$ \\
\hline & 2 & $\begin{array}{c}0.244 \\
\pm 0.017^{\mathrm{ab}}\end{array}$ & $\begin{array}{c}0.312 \\
\pm 0.007^{\mathrm{ab}}\end{array}$ & $\begin{array}{c}0.355 \\
\pm 0.006^{\mathrm{ab}}\end{array}$ & $\begin{array}{c}0.392 \\
\pm 0.008 \mathrm{a}^{\mathrm{b}}\end{array}$ & $\begin{array}{c}0.336 \\
\pm 0.009^{\mathrm{b}}\end{array}$ \\
\hline & 4 & $\begin{array}{c}0.227 \\
\pm 0.008^{\mathrm{b}}\end{array}$ & $\begin{array}{c}0.291 \\
\pm 0.009^{\mathrm{ab}}\end{array}$ & $\begin{array}{c}0.341 \\
\pm 0.011^{\mathrm{ab}}\end{array}$ & $\begin{array}{c}0.387 \\
\pm 0.009^{\mathrm{ab}} \\
\end{array}$ & $\begin{array}{c}0.314 \\
\pm 0.011^{\mathrm{c}}\end{array}$ \\
\hline & 6 & $\begin{array}{c}0.208 \\
\pm 0.013^{\mathrm{c}}\end{array}$ & $\begin{array}{c}0.296 \\
\pm 0.004^{\mathrm{b}}\end{array}$ & $\begin{array}{c}0.336 \\
\pm 0.021^{\mathrm{b}}\end{array}$ & $\begin{array}{c}0.373 \\
\pm 0.012^{\mathrm{b}}\end{array}$ & $\begin{array}{c}0.304 \\
\pm 0.009^{c}\end{array}$ \\
\hline \multirow{4}{*}{$\begin{array}{c}\text { Total sugars } \\
\mathrm{g} / 100 \mathrm{~g}\end{array}$} & Zero time & $\begin{array}{l}40.25 \\
\pm 1.14^{\mathrm{a}}\end{array}$ & $\begin{array}{l}52.60 \\
\pm 0.7^{\mathrm{a}}\end{array}$ & $\begin{array}{c}62.73 \\
\pm 0.27^{\mathrm{a}}\end{array}$ & $\begin{array}{l}71.27 \\
\pm 0.77^{\mathrm{a}}\end{array}$ & $\begin{array}{c}71.84 \\
\pm 0.89^{\mathrm{a}}\end{array}$ \\
\hline & 2 & $\begin{array}{l}39.35 \\
\pm 0.7^{\mathrm{ab}}\end{array}$ & $\begin{array}{c}51.89 \\
\pm 0.21^{\text {ab }}\end{array}$ & $\begin{array}{c}61.84 \\
\pm 0.57^{\mathrm{ab}} \\
\end{array}$ & $\begin{array}{c}69.76 \\
\pm 1.76^{\text {ab }} \\
\end{array}$ & $\begin{array}{c}69.62 \\
\pm 0.38^{\mathrm{b}}\end{array}$ \\
\hline & 4 & $\begin{array}{c}38.88 \\
\pm 0.32^{\mathrm{ab}}\end{array}$ & $\begin{array}{l}50.80 \\
\pm 0.5^{\mathrm{ab}}\end{array}$ & $\begin{array}{l}60.55 \\
\pm 0.2^{\mathrm{bc}}\end{array}$ & $\begin{array}{c}68.72 \\
\pm 0.28^{\mathrm{b}}\end{array}$ & $\begin{array}{c}68.03 \\
\pm 0.47^{c}\end{array}$ \\
\hline & 6 & $\begin{array}{l}38.07 \\
\pm 0.93^{b}\end{array}$ & $\begin{array}{l}50.07 \\
\pm 0.23^{\mathrm{b}}\end{array}$ & $\begin{array}{l}59.70 \\
\pm 0.7^{c}\end{array}$ & $\begin{array}{l}67.96 \\
\pm 0.14^{\mathrm{b}}\end{array}$ & $\begin{array}{c}66.55 \\
\pm 0.55^{\mathrm{d}}\end{array}$ \\
\hline \multirow{4}{*}{$\begin{array}{l}\text { Reducing sugars } \\
\mathrm{g} / 100 \mathrm{~g}\end{array}$} & Zero time & $\begin{array}{c}18.11 \\
\pm 0.11^{\mathrm{a}}\end{array}$ & $\begin{array}{c}24.63 \\
\pm 0.63^{\mathrm{a}}\end{array}$ & $\begin{array}{l}29.60 \\
\pm 0.6^{\mathrm{a}}\end{array}$ & $\begin{array}{c}34.43 \\
\pm 0.43^{\mathrm{a}}\end{array}$ & $\begin{array}{c}34.83 \\
\pm 0.33^{\mathrm{a}}\end{array}$ \\
\hline & 2 & $\begin{array}{c}18.39 \\
\pm 0.39^{\mathrm{ab}} \\
\end{array}$ & $\begin{array}{c}25.11 \\
\pm 0.61^{\text {ab }}\end{array}$ & $\begin{array}{c}30.33 \\
\pm 0.43^{\mathrm{ab}}\end{array}$ & $\begin{array}{c}34.56 \\
\pm 0.56^{\mathrm{ab}} \\
\end{array}$ & $\begin{array}{c}34.95 \\
\pm 0.65^{\mathrm{ab}}\end{array}$ \\
\hline & 4 & $\begin{array}{c}18.66 \\
\pm 0.36^{\mathrm{ab}}\end{array}$ & $\begin{array}{l}25.30 \\
\pm 0.4^{\mathrm{ab}}\end{array}$ & $\begin{array}{l}30.41 \\
\pm .51^{\text {ab }}\end{array}$ & $\begin{array}{l}34.63 \\
\pm .53^{\mathrm{ab}} \\
\end{array}$ & $\begin{array}{c}35.12 \\
\pm 0.65^{\mathrm{ab}}\end{array}$ \\
\hline & 6 & $\begin{array}{l}18.77 \\
\pm 0.7^{\mathrm{b}}\end{array}$ & $\begin{array}{c}25.55 \\
\pm 0.45^{\mathrm{b}}\end{array}$ & $\begin{array}{l}30.60 \\
\pm .31^{\mathrm{b}}\end{array}$ & $\begin{array}{c}34.71 \\
\pm 0.43^{b}\end{array}$ & $\begin{array}{l}35.25 \\
\pm 0.5^{\mathrm{b}}\end{array}$ \\
\hline \multirow{4}{*}{$\begin{array}{l}\text { Non-reducing } \\
\text { sugars } g / 100 g\end{array}$} & Zero time & $\begin{array}{l}22.14 \\
\pm 0.24^{\mathrm{a}}\end{array}$ & $\begin{array}{l}27.97 \\
\pm 0.87^{\mathrm{a}}\end{array}$ & $\begin{array}{c}33.13 \\
\pm 0.28^{\mathrm{a}}\end{array}$ & $\begin{array}{l}36.84 \\
\pm 0.7^{\mathrm{a}}\end{array}$ & $\begin{array}{c}37.01 \\
\pm 0.61^{\mathrm{a}}\end{array}$ \\
\hline & 2 & $\begin{array}{l}20.96 \\
\pm 0.46^{\mathrm{b}} \\
\end{array}$ & $\begin{array}{c}26.78 \\
\pm 0.38^{\mathrm{ab}}\end{array}$ & $\begin{array}{c}31.51 \\
\pm 0.51^{\mathrm{ab}}\end{array}$ & $\begin{array}{l}35.20 \\
\pm 0.4^{\mathrm{ab}}\end{array}$ & $\begin{array}{c}34.67 \\
\pm 0.57^{\mathrm{b}}\end{array}$ \\
\hline & 4 & $\begin{array}{c}20.22 \\
\pm 0.17 b^{c}\end{array}$ & $\begin{array}{l}25.50 \\
\pm 0.50^{\mathrm{b}}\end{array}$ & $\begin{array}{c}30.14 \\
\pm 0.34^{\mathrm{b}}\end{array}$ & $\begin{array}{c}34.09 \\
\pm 0.29^{\mathrm{ab}}\end{array}$ & $\begin{array}{c}32.91 \\
\pm 0.41^{c}\end{array}$ \\
\hline & 6 & $\begin{array}{c}19.30 \\
\pm 0.37^{c}\end{array}$ & $\begin{array}{c}24.52 \\
\pm 0.62^{c}\end{array}$ & $\begin{array}{l}29.10 \\
\pm 0.49^{c}\end{array}$ & $\begin{array}{c}33.25 \\
\pm 0.53^{\mathrm{b}}\end{array}$ & $\begin{array}{l}31.30 \\
\pm 0.6^{c}\end{array}$ \\
\hline
\end{tabular}

dehydrated to about $55 \%$ moisture content, coated mango slices.

$\mathrm{T}_{2}$ : Osmotic dehydrated, partially air dehydrated to about $40 \%$ moisture content, coated mango slices. $\mathrm{T}_{3}$ : Osmotic dehydrated, partially air dehydrated to about $30 \%$ moisture content, coated mango slices. $\mathrm{T}_{3}$ : Osmotic dehydrated, partially air dehydrated to about $20 \%$ moisture content, coated mango slices. $T_{5}$ : Osmotic dehydrated, partially air dehydrated to about $20 \%$ moisture content without coating mango slices (control). 
treated with osmotic dehydration only. While, control treatment (dried mango slices without coating) show highly decrease than other one. The results demonstrated that the coatings prolonged the shelf life of the mango slices by slowing down the metabolism as indicated by the retention of acidity, and retarded production of reducing sugars (Velickova et al., ,2013). Results in table (5) show the non- reducing sugars decreased during storage of all samples and this increment was more obvious in $\left(T_{5}\right.$ and $\left.T_{1}\right)$ than other samples. The increase in reducing sugars could be attributed to hydrolysis of non-reducing sugars to reducing sugars.

\section{Effect of edible coating and moisture content on antioxidant compounds of osmotic dehydrated and partially air dehydrated mango slices during storage.}

The obtained results in table (6) show a sever decrease in ascorbic acid parallel with storage time prolonged in all mango samples especially control one. The increase of ascorbic loss correlated to the increase of coated sample moisture content is not entirely due to the dilution of the ascorbic acid but partly to the effect of moisture itself (Hymavathi and Khader, 2005). On the other hand, ascorbic acid of control sample showed the highest decrease comparing the other samples. It may be due to oxygen in packaging which led to oxidation of ascorbic acid during storage periods while; edible coating prevents passage of oxygen to coated slices.

The results in Table (6) indicate that the total phenols of coated mango slices treatment showed the decreasing during storage periods. Also, the same data indicate that, the total phenols showed highly decreased in $\left(T_{1}\right)$ than comparing coated partially air dehydrated sample during storage. On the other hand control treatment showed the highest degradation of total phenols; it may be due to oxidation of phenolic compounds with oxygen.

Retention carotenoids were higher in coated partially air dehydrated mango slices treatments than non coated dried osmotic dehydrated mango slices (control) during storage. It could be due to edible coatings which reduce moisture transfer, restrict oxygen uptake and lower respiration.

Antioxidant activity reduced for all mango slices indicating loss of the bioactive compounds during storage. Control sample showed the highest reduction in antioxidant activity compared with the other samples. 
Table 6. Antioxidant compounds of osmotic dehydrated and partially air dehydrated coated mango slices during storage

\begin{tabular}{|c|c|c|c|c|c|c|}
\hline \multirow{2}{*}{ Properties } & \multirow{2}{*}{$\begin{array}{c}\text { torage period } \\
\text { (month) }\end{array}$} & \multicolumn{5}{|c|}{ Ssmotic dehydrated and partially air dehydrated mango slices } \\
\hline & & $\mathrm{T}_{1}$ & $\mathrm{~T}_{2}$ & $\mathrm{~T}_{3}$ & $\mathrm{~T}_{4}$ & $T_{5}$ \\
\hline \multirow{4}{*}{$\begin{array}{l}\text { Ascorbic acid } \\
\mathrm{mg} / 100 \mathrm{~g}\end{array}$} & Zero time & $\begin{array}{l}53.10 \\
\pm 0.9^{\mathrm{a}}\end{array}$ & $\begin{array}{c}66.12 \\
\pm 0.42^{\mathrm{a}}\end{array}$ & $\begin{array}{c}75.06 \\
\pm 1.06^{\mathrm{a}}\end{array}$ & $\begin{array}{l}80.80 \\
\pm 1.4^{\mathrm{a}}\end{array}$ & $\begin{array}{c}80.29 \\
\pm 0.79^{a}\end{array}$ \\
\hline & 2 & $\begin{array}{c}44.51 \\
\pm 0.71^{\mathrm{b}} \\
\end{array}$ & $\begin{array}{c}56.43 \\
\pm 1.23^{\mathrm{b}} \\
\end{array}$ & $\begin{array}{c}66.49 \\
\pm 1.38^{\mathrm{b}} \\
\end{array}$ & $\begin{array}{l}71.94 \\
\pm 1.2^{\mathrm{b}} \\
\end{array}$ & $\begin{array}{c}64.93 \\
\pm 1.43^{\mathrm{b}} \\
\end{array}$ \\
\hline & 4 & $\begin{array}{c}38.29 \\
\pm 1.19^{c}\end{array}$ & $\begin{array}{c}50.39 \\
\pm 0.59^{c}\end{array}$ & $\begin{array}{c}60.13 \\
\pm 0.83^{c}\end{array}$ & $\begin{array}{c}65.24 \\
\pm 0.63^{\mathrm{c}}\end{array}$ & $\begin{array}{c}47.17 \\
\pm 1.06^{c}\end{array}$ \\
\hline & 6 & $\begin{array}{c}34.46 \\
\pm 0.66^{d}\end{array}$ & $\begin{array}{l}46.12 \\
\pm 0.22^{d}\end{array}$ & $\begin{array}{l}55.60 \\
\pm 1.49^{d}\end{array}$ & $\begin{array}{l}61.03 \\
\pm 1.0^{\mathrm{d}}\end{array}$ & $\begin{array}{l}44.06 \\
\pm 0.95^{d}\end{array}$ \\
\hline \multirow{4}{*}{$\begin{array}{l}\text { Phenolic compounds } \\
\mathrm{mg} / 100 \mathrm{~g}\end{array}$} & Zero time & $\begin{array}{l}43.74 \\
\pm 1.7^{\mathrm{a}}\end{array}$ & $\begin{array}{l}55.97 \\
\pm 0.77^{\mathrm{a}}\end{array}$ & $\begin{array}{c}65.26 \\
\pm 1.15^{\mathrm{a}}\end{array}$ & $\begin{array}{c}71.98 \\
\pm 0.78^{\text {a }}\end{array}$ & $\begin{array}{c}72.52 \\
\pm 0.52^{\mathrm{a}}\end{array}$ \\
\hline & 2 & $\begin{array}{c}39.25 \\
\pm 0.35^{\mathrm{b}}\end{array}$ & $\begin{array}{c}51.23 \\
\pm 0.33^{b}\end{array}$ & $\begin{array}{c}60.39 \\
\pm 0.39^{b}\end{array}$ & $\begin{array}{c}67.36 \\
\pm 0.46^{\mathrm{b}}\end{array}$ & $\begin{array}{c}63.65 \\
\pm 0.65^{\mathrm{b}}\end{array}$ \\
\hline & 4 & $\begin{array}{l}36.68 \\
\pm 0.68^{\mathrm{c}} \\
\end{array}$ & $\begin{array}{c}48.29 \\
\pm 0.49^{c}\end{array}$ & $\begin{array}{c}56.38 \\
\pm 1.26^{c} \\
\end{array}$ & $\begin{array}{l}64.10 \\
\pm 0.7^{c}\end{array}$ & $\begin{array}{c}56.23 \\
\pm 0.43^{c} \\
\end{array}$ \\
\hline & 6 & $\begin{array}{l}34.30 \\
\pm 0.7^{d}\end{array}$ & $\begin{array}{c}46.08 \\
\pm 0.58^{d}\end{array}$ & $\begin{array}{c}53.86 \\
\pm 0.86^{d}\end{array}$ & $\begin{array}{c}61.79 \\
\pm 0.79^{d}\end{array}$ & $\begin{array}{c}54.19 \\
\pm 0.69^{\mathrm{d}}\end{array}$ \\
\hline \multirow{4}{*}{$\begin{array}{l}\text { Total carotenoids } \\
\mathrm{mg} / 100 \mathrm{~g}\end{array}$} & Zero time & $\begin{array}{c}9.95 \\
\pm 0.74^{\mathrm{a}}\end{array}$ & $\begin{array}{c}12.79 \\
\pm 0.48^{\mathrm{a}}\end{array}$ & $\begin{array}{l}15.00 \\
\pm 0.4^{\mathrm{a}}\end{array}$ & $\begin{array}{c}16.73 \\
\pm 0.53^{\mathrm{a}}\end{array}$ & $\begin{array}{c}16.87 \\
\pm 0.65^{\mathrm{a}}\end{array}$ \\
\hline & 2 & $\begin{array}{c}9.12 \\
\pm 0.37^{\mathrm{ab}}\end{array}$ & $\begin{array}{c}11.78 \\
\pm 0.58^{\mathrm{ab}}\end{array}$ & $\begin{array}{c}13.88 \\
\pm 0.38^{\mathrm{b}}\end{array}$ & $\begin{array}{c}15.65 \\
\pm 0.29^{\mathrm{b}}\end{array}$ & $\begin{array}{c}15.54 \\
\pm 0.54^{\mathrm{b}}\end{array}$ \\
\hline & 4 & $\begin{array}{c}8.62 \\
\pm 0.51^{\text {bc }}\end{array}$ & $\begin{array}{c}11.08 \\
\pm 0.55^{b}\end{array}$ & $\begin{array}{c}13.09 \\
\pm 0.29^{\mathrm{bc}}\end{array}$ & $\begin{array}{c}14.79 \\
\pm 0.59^{\text {bc }}\end{array}$ & $\begin{array}{c}13.76 \\
\pm 0.76^{c}\end{array}$ \\
\hline & 6 & $\begin{array}{c}7.93 \\
\pm 0.68^{\mathrm{c}}\end{array}$ & $\begin{array}{c}10.66 \\
\pm 0.66^{\mathrm{b}}\end{array}$ & $\begin{array}{c}12.57 \\
\pm 0.57^{c}\end{array}$ & $\begin{array}{c}14.21 \\
\pm 0.41^{\mathrm{c}}\end{array}$ & $\begin{array}{l}13.03 \\
\pm .63^{c}\end{array}$ \\
\hline \multirow{4}{*}{ Antioxidant activity \% } & Zero time & $\begin{array}{r}48.32 \\
\pm 1.22^{\mathrm{a}} \\
\end{array}$ & $\begin{array}{c}44.11 \\
\pm 0.61^{\mathrm{a}} \\
\end{array}$ & $\begin{array}{c}40.21 \\
\pm 0.71^{\mathrm{a}} \\
\end{array}$ & $\begin{array}{l}36.10 \\
\pm 0.32^{\mathrm{a}} \\
\end{array}$ & $\begin{array}{c}35.62 \\
\pm 0.62^{a} \\
\end{array}$ \\
\hline & 2 & $\begin{array}{l}43.32 \\
\pm 0.82^{b}\end{array}$ & $\begin{array}{l}40.60 \\
\pm 0.60^{b}\end{array}$ & $\begin{array}{l}37.97 \\
\pm 0.97^{b}\end{array}$ & $\begin{array}{l}34.60 \\
\pm 0.6^{\mathrm{b}}\end{array}$ & $\begin{array}{c}31.79 \\
\pm 0.79^{\mathrm{b}}\end{array}$ \\
\hline & 4 & $\begin{array}{c}39.81 \\
\pm 0.81^{c}\end{array}$ & $\begin{array}{l}37.43 \\
\pm 043^{c}\end{array}$ & $\begin{array}{c}36.41 \\
\pm 0.41^{c}\end{array}$ & $\begin{array}{c}32.92 \\
\pm 0.92^{c}\end{array}$ & $\begin{array}{c}29.56 \\
\pm 0.56^{c}\end{array}$ \\
\hline & 6 & $\begin{array}{c}35.42 \\
\pm 0.42^{d}\end{array}$ & $\begin{array}{c}36.81 \\
\pm 0.88^{\mathrm{d}}\end{array}$ & $\begin{array}{c}34.88 \\
\pm 0.88^{\mathrm{d}}\end{array}$ & $\begin{array}{c}31.76 \\
\pm 0.76^{\mathrm{d}}\end{array}$ & $\begin{array}{c}27.12 \\
\pm 0.62^{\mathrm{d}}\end{array}$ \\
\hline
\end{tabular}

Means with a column showing the same letter are not significantly different $(p>0.5) . T_{1}$ : Osmotic dehydrated to about 55\% moisture content, coated mango slices.

$\mathbf{T}_{\mathbf{2}}$ : Osmotic dehydrated, partially air dehydrated to about $40 \%$ moisture content, coated mango slices. $\mathbf{T}_{\mathbf{3}}$ : Osmotic dehydrated, partially air dehydrated to about 30\%moisture content, coated mango slices. $\mathbf{T}_{\mathbf{3}}$ : Osmotic dehydrated, partially air dehydrated to about $20 \%$ moisture content, coated mango slices. $\mathbf{T}_{\mathbf{5}}$ : Osmotic dehydrated, partially air dehydrated to about $20 \%$ moisture content without coating mango slices (control). 
Effect of edible coating and moisture content on total microbial counts and yeast \&moulds (log CFU/g) of osmotic dehydrated and partially air dehydrated mango slices during storage.

Total count as well as yeast and mould were decreased during partially dehydration. This could be attributed to the low moisture content as well as

Table 7. Total count and yeast \& mould (Log CFU/g) of partially air dehydrated coated mango slices during storage

\begin{tabular}{|c|c|c|c|c|c|c|}
\hline \multirow[t]{2}{*}{ Properties } & \multirow{2}{*}{$\begin{array}{c}\text { Storage } \\
\text { period (month) }\end{array}$} & \multicolumn{5}{|c|}{ Dsmotic dehydrated and partially air dehydrated mango slices } \\
\hline & & $\mathrm{T}_{1}$ & $\mathrm{~T}_{2}$ & $\mathrm{~T}_{3}$ & $\mathrm{~T}_{4}$ & $T_{5}$ \\
\hline \multirow{4}{*}{$\begin{array}{l}\text { Total count } \\
\text { (Log CFU/g) }\end{array}$} & Zero time & 2.54 & 2.39 & 2.30 & 2.17 & 2.11 \\
\hline & 2 & 2.62 & 2.47 & 2.38 & 2.25 & 2.40 \\
\hline & 4 & 2.69 & 2.54 & 2.49 & 2.34 & 2.50 \\
\hline & 6 & 2.87 & 2.60 & 2.55 & 2.41 & 2.66 \\
\hline \multirow{4}{*}{$\begin{array}{l}\text { Yeast \&moulds } \\
\text { (Log CFU/g) }\end{array}$} & Zero time & 1.39 & 1.17 & 1.00 & 0.69 & 0.70 \\
\hline & 2 & 1.54 & 1.30 & 1.07 & 1.01 & 1.11 \\
\hline & 4 & 1.70 & 1.39 & 1.25 & 1.23 & 1.30 \\
\hline & 6 & 1.82 & 1.47 & 1.38 & 1.27 & 1.33 \\
\hline
\end{tabular}

$\mathbf{T}_{\mathbf{1}}$ : Osmotic dehydrated to about $55 \%$ moisture content, coated mango slices.

$\mathbf{T}_{\mathbf{2}}$ : Osmotic dehydrated, partially air dehydrated to about $40 \%$ moisture content, coated mango slices. $\mathbf{T}_{\mathbf{3}}$ : Osmotic dehydrated, partially air dehydrated to about 30\%moisture content, coated mango slices. $\mathbf{T}_{3}$ : Osmotic dehydrated, partially air dehydrated to about $20 \%$ moisture content, coated mango slices. $\mathbf{T}_{\mathbf{5}}$ : Osmotic dehydrated, partially air dehydrated to about $20 \%$ moisture content without coating mango slices (control).

the addition of potassium sorbate during osmotic dehydration and steam treatment . Also, results in table (7) show that, total count as well as yeast and moulds were slightly increased during storage. Edible coatings could reduce moisture transfer, restrict oxygen uptake, lower respiration, seal in flavor volatiles and retard microbial growth, potential discoloration and chtiosan - methyl cellulose film coatings for their potential to enhance the quality and extend the storage life of food products (Elsabee and Abdou, 2013).

\section{Effect of edible coating and moisture content on sensory evaluation of osmotic dehydrated and partially air dehydrated mango slices during storage.}

Sensory quality attributes for coated partially air dehydrated mango slices immediately after processing and during storage for 6 month at $25{ }^{\circ} \mathrm{C}$ are presented in Table (8). Color is very important quality characteristic of coated mango slices, the 
yellowing of the fruit subjected to degradation which is easily noticeable in control and $\left(T_{1}\right)$ after 2 month during storage.

Table 8. Sensory evaluation of osmotic dehydrated and partially air dehydrated coated mango slices during storage

\begin{tabular}{|c|c|c|c|c|c|c|}
\hline \multirow{2}{*}{ Properties } & \multirow{2}{*}{$\begin{array}{l}\text { Storage } \\
\text { period } \\
\text { (month) }\end{array}$} & \multicolumn{5}{|c|}{ Osmotic dehydrated and partially air dehydrated mango slices } \\
\hline & & $\mathrm{T}_{1}$ & $\mathrm{~T}_{2}$ & $\mathrm{~T}_{3}$ & $\mathrm{~T}_{4}$ & $\mathrm{~T}_{5}$ \\
\hline \multirow{4}{*}{ Color } & Zero time & $9.1^{\mathrm{a}} \pm 0.28$ & $8.5^{\mathrm{a}} \pm 0.35$ & $8.2^{\mathrm{ab}} \pm 0.31$ & $7.5^{b} \pm 0.52$ & $7.4^{\mathrm{b}} \pm 0.41$ \\
\hline & 2 & $7.9^{\mathrm{ab}} \pm 0.36$ & $8.1^{\mathrm{ab}} \pm 0.22$ & $7.8^{\mathrm{ab}} \pm 0.45$ & $7.1^{b} \pm 0.56$ & $7.0^{\mathrm{b}} \pm 0.62$ \\
\hline & 4 & $6.5^{\mathrm{bc}} \pm 0.37$ & $7.9{ }^{\mathrm{ab}} \pm 0.41$ & $7.7^{\mathrm{ab}} \pm 0.50$ & $6.5^{\mathrm{bc}} \pm 0.67$ & $6.4^{\mathrm{bc}} \pm 0.54$ \\
\hline & 6 & $5.0^{d} \pm 0.75$ & $7.8^{\mathrm{ab}} \pm 0.67$ & $7.6^{\mathrm{ab}} \pm 0.49$ & $6.0^{\mathrm{c}} \pm 0.33$ & $6.0^{\mathrm{c}} \pm 0.43$ \\
\hline \multirow{4}{*}{ Taste } & Zero time & $9.5^{\mathrm{a}} \pm 0.28$ & $9.4^{\mathrm{a}} \pm 0.23$ & $9.1^{\mathrm{a}} \pm 0.41$ & $7.6^{\mathrm{ab}} \pm 0.62$ & $7.5^{\mathrm{ab}} \pm 0.79$ \\
\hline & 2 & $7.6^{\mathrm{ab}} \pm 0.39$ & $9.0^{\mathrm{a}} \pm 0.52$ & $8.5^{\mathrm{a}} \pm 0.35$ & $7.0^{b} \pm 0.78$ & $6.9^{b c} \pm 0.51$ \\
\hline & 4 & $6.9^{b c} \pm 0.87$ & $8.2^{\mathrm{ab}} \pm 0.65$ & $8.0^{\mathrm{ab}} \pm 0.48$ & $6.5^{\mathrm{bc}} \pm 0.64$ & $6.5^{b c} \pm 0.66$ \\
\hline & 6 & $6.0^{\mathrm{c}} \pm 0.91$ & $8.0^{\mathrm{ab}} \pm 0.71$ & $7.8^{\mathrm{ab}} \pm 0.33$ & $6.0^{c} \pm 0.55$ & $6.0^{c} \pm 0.74$ \\
\hline \multirow{4}{*}{ Texture } & Zero time & $9.5^{\mathrm{a}} \pm 0.25$ & $8.5^{\mathrm{a}} \pm 0.11$ & $8.0^{\mathrm{ab}} \pm 0.42$ & $6.9^{b c} \pm 0.83$ & $6.8^{\mathrm{bc}} \pm 0.89$ \\
\hline & 2 & $6.9^{b c} \pm 0.28$ & $8.0^{\mathrm{ab}} \pm 0.24$ & $7.9^{\mathrm{ab}} \pm 0.33$ & $6.4^{\mathrm{bc}} \pm 0.79$ & $6.5^{\mathrm{bc}} \pm 0.70$ \\
\hline & 4 & $6.0^{c} \pm 0.82$ & $7.8^{\mathrm{ab}} \pm 0.37$ & $7.6^{\mathrm{ab}} \pm 0.45$ & $5.9^{c} \pm 0.65$ & $6.3^{\mathrm{C}} \pm 0.72$ \\
\hline & 6 & $5.0^{d} \pm 0.60$ & $7.5^{b} \pm 0.51$ & $7.3^{b} \pm 0.66$ & $5.5^{\mathrm{cd}} \pm 0.81$ & $6.2^{c} \pm 0.54$ \\
\hline \multirow{4}{*}{ Flavor } & Zero time & $8.0^{\mathrm{ab}} \pm 0.27$ & $7.8^{\mathrm{ab}} \pm 0.56$ & $7.7^{\mathrm{ab}} \pm 0.49$ & $6.5^{\mathrm{bc}} \pm 0.21$ & $6.5^{\mathrm{bc}} \pm 0.34$ \\
\hline & 2 & $7.2^{b} \pm 0.30$ & $7.6^{\mathrm{ab}} \pm 0.49$ & $7.4^{b} \pm 0.66$ & $6.0^{c} \pm 0.30$ & $5.8^{\mathrm{c}} \pm 0.43$ \\
\hline & 4 & $5.6^{c} \pm 0.75$ & $7.0^{b} \pm 0.62$ & $7.1^{b} \pm 0.52$ & $5.7^{c} \pm 0.45$ & $5.2^{c d} \pm 0.32$ \\
\hline & 6 & $5.1^{d} \pm 0.90$ & $6.5^{\mathrm{bc}} \pm 0.52$ & $6.4^{\mathrm{bc}} \pm 0.45$ & $5.3^{d} \pm 0.62$ & $5.0^{d} \pm 0.45$ \\
\hline
\end{tabular}

Values within a column with the same letter are not significantly different $(p>0.05)$

$\mathbf{T}_{\mathbf{1}}$ : Osmotic dehydrated to about $55 \%$ moisture content, coated mango slices.

$\mathbf{T}_{\mathbf{2}}$ : Osmotic dehydrated, partially air dehydrated to about $40 \%$ moisture content, coated mango slices. $\mathbf{T}_{\mathbf{3}}$ : Osmotic dehydrated, partially air dehydrated to about $30 \%$ moisture content, coated mango slices. $\mathbf{T}_{\mathbf{3}}$ : Osmotic dehydrated, partially air dehydrated to about $20 \%$ moisture content, coated mango slices $\mathbf{T}_{5}$ : Osmotic dehydrated, partially air dehydrated to about $20 \%$ moisture content without coating mango slices (control).

While, the color of treatments $\left(T_{2}\right.$ and $\left.T_{3}\right)$ were not differ significantly during storage till the end of storage. On the other hand, $\left(T_{4}\right.$ and $\left.T_{5}\right)$ sample has the lowest color score value at zero time. It could be due to the long time of air drying to reach moisture content about $20 \%$ and the reaction amino acids and sugars during drying. Taste scores of the treatments $\left(T_{1}, T_{2}\right.$ and $\left.T_{3}\right)$ sliced mango fruit were still commercially satisfactory after storage period of two months. However, after six months of storage; the $\left(T_{1}\right)$ became unacceptable for the market whereas the good quality of the partially dried and chtiosan - methyl cellulose film coated sliced fruit $\left(T_{2}\right.$ and $T_{3}$ ) were retained. It could be due to high moisture content of $\left(T_{1}\right)$, which led to accelerate deterioration of quality factors of sample during storage. Also, taste score of $\left(T_{4}\right.$ and $\left.T_{5}\right)$ sample showed more significant decreasing comparing other treatments at zero time and continuously until the end of storage. It may be due to high sugars 
and low moisture of these samples. Chien, et al.,(2007) reported that chitosan coating improved the quality and extended the shelf life of sliced mango. With regard to texture of mango slices, results in Table (8) indicate that texture scores of the coated mango slices prepared with osmotic dehydrated ,partially air dehydrated $\left(T_{1}, T_{2}\right.$ and $\left.T_{3}\right)$ had higher scores than those of the mango slices prepared with osmotic dehydrated and air drying technique and or coating ( $\mathrm{T}_{4}$ and control treatment). Extending storage time (6months) of mango slices prepared with osmoair dehydration and coated $\left(T_{2}\right.$ and $\left.T_{3}\right)$ had no significant effect on the texture of the coated partially mango slices. Texture scores of $\left(T_{4}\right.$ and $\left.T_{5}\right)$ sample showed the lowest value at zero time due to the reduction level moisture content. Results in Table (8) indicate that extending storage time of the dehydrated mango slices prepared with air dehydration (control treatment) for 6 months was accompanied by a significant decrease in the flavor score of the form to $\sim 5$ score. Also, the same table show that extending of storage time had no significant effect on the flavor of treatment $\left(T_{2}\right.$ and $T_{3}$ ) mango slices while, flavor scores of treatment $\left(T_{1}\right)$ was accompanied by a significant decrease after 2 month of storage.

In conclusion, the maintenance of quality and the extension of the shelf life of sliced mango fruit by osmotic and or partially air dehydration to moisture content 55,40 and $30 \%$ then, edible coating with chtiosan - methyl cellulose film can be considered as commercial application during storage and marketing.

\section{REFERENCES}

1. Alothman M., R. Bhat and A.A. Karim. 2009. Antioxidant capacity and phenolic content of selected tropical fruits from Malaysia, extracted with different solvents. Food Chemistry, 115, 785-788.

2. Assous M.T.M. 2004. Effect of ultrasound during osmotic dehydration on the quality of dehydrated tropical fruits. Ph.D. Thesis, Food Sci. and Technol. Dept., Fac. of Agric., Cairo Univ., Egypt.

3. A.O.A.C. 2005. Official Methods of Analysis of AOAC. International18th Edition, Published by AOAC International. Maryland 20877- 2417. USA.

4. Chien , P., F. Sheu and F. Yang. 2007. Effects of edible chitosan coating on quality and shelf life of sliced mango fruit. Journal of Food Engineering 78 ,225229.

5. Chiumarelli, M., C.C. Ferrari, C.I.G.L. Sarant poulos and M.D. Hubinger. 2011. Fresh cut 'Tommy Atkins' mango pre-treated with citric acid and coated with 
cassava (Manihot esculenta Crantz) starch or sodium alginate. Innovative Food Science and Emerging Technologies 12, 381-387.

6. Collins, C.H. and P.M. Lyne. 1976. Microbiological methods.Butterworths and Co. (publishers) Ltd. London.

7. Djioua,T., F. Charles, F. Lopez-Lauri, H. Filgueiras, A. Coudret, M. Freire, M. Ducamp- Collin and H. Sallanon. 2009. Improving the storage of minimally processed mangoes (Mangifera indica L.) by hot water treatments. Postharvest Biology and Technology 52,221-226.

8. Elsabee M.Z. and E.S. Abdou. 2013. Chitosan based edible films and coatings: A review. Materials Science and Engineering C $33,1819-1841$.

9. FAO. 2013. Food and Agriculture Organization of United Nations. Statistics Division .

10. Giraldo, G., P. Talens, P. Fito and A. Chiralt. 2003. Influence of sucrose solution concentration on kinetics and yield during osmotic dehydration of mango. J. Food Eng. 58: $33-43$.

11. Hymavathi,T.V. and V. Khader. 2005. Carotene,ascorbic acid and sugar content of vacuum dehydrated ripe mango powders stored in flexible Packaging material. Journal of Food Composition and Analysis 18,181-192.

12. Kim, S. H., H. K. No, S. D. Kim and W. Prinyawiwatkul. 2006. Effect of plasticizer concentration and solvent types on shelf-life of Eggs coated with chitosan. Journal of Food Science, 71: 349-357.

13. Liu,F. Fu,S., Bi,X., F. Chen, X. Liao, X. Hu and J. Wu. 2013. Physico-chemical and antioxidant properties of four mango (Mangifera indica L.) cultivars in China. Food Chemistry 138, 396-405.

14. Liu, H. R. 2003. Health benefits of fruit and vegetables are from additive and synergistic combinations of phytochemicals. American Journal of Clinical Nutrition, 78: 517-520.

15. Maskan, M. 2001. Deyhdartion, shrinkage and rehydration characteristics of kiwifruits during hot air and microwave deyhdartion.J. Food Eng. 48: 177 - 182.

16. Olivas, G.I. and G.V. Barbosa-Canovas. 2005. Edible coatings for fresh-cut fruits. Crit.Rev. Food Sci. Nutr. 45, 657-670.

17. Pott, I., M. Marx, S. Neidhart, W. Muhlbauer and R. Carle. 2003. Quantitative determination of b-carotene stereoisomers in fresh, dried, and solar-dried mangoes (Mangifera indica L.). Journal of Agricultural and Food Chemistry, 51, $4527-4531$. 
18. Pranoto, Y., S. K. Rakshit and V. M. Salokhe. 2005. Enhancing antimicrobial activity of chitosan films by incorporating garlic oil, potassium sorbate and nisin. LWT - Food Science and Technology, 38: 859-865.

19. Ranganna, S. 1977. Manual of analysis of fruit and vegetable products. Tata McGraw-Hill Publishing Company Limited, NewDelhi.

20. Raybaudi-Massilia, R.M., J. Mosqueda-Melgar and O. Martín-elloso. 2008. Edible alginate- based coating as carrier of antimicrobials to improve shelf-life and safety of fresh-cut melon. International Journal of Food Microbiology 121, 313327.

21. Robles-Sánchez, R. M., M.A. Rojas-Graü, I. Odriozola-Serrano, G. González-guilar and o. Martin- Belloso. 2013. Influence of alginate-based edible coating as carrier of antibrowning agents on bioactive compounds and antioxidant activity in freshcut Kent mangoes. LWT - Food Science and Technology, 50: 240-246.

22. Rojas- Grau, M.A, R.S. Fortuny and O. Martn-Belloso. 2009. Edible coatings to incorporate active ingredients to fresh cut fruits: a review. Trends in Food Science \& Technology 20,438-447.

23. SPSS. 1999. SPSS for Windows Release 9.0.0. SPSS Inc. Chicago, IL.

24. Talens,P. Pérez-Masia, R. Fabra, M.J., Vargas, M. and Chiralt, A. 2012. Application of edible coatings to partially air dehydrated pineapple for use in fruit-cereal products. Journal of Food Engineering 112, 86-93.

25. Van Arsdel, W.B. and M.J. Copley. (Eds.) 1964. Food Dehydration. AVI Publishing Co. Inc., Westport, Connecticut.

26. Velickova, E., E. Winkelhausen, S. Kuzmanova, V.D. Alves and M. MoldaoMartins. 2013. Impact of chitosan-beeswax edible coatings on the quality of fresh strawberries (Fragaria ananassa cv Camarosa) under commercial storage conditions. LWT - Food Science and Technology 52, 80-90. 


\section{إنتاج وتقييم شرائح المانجو المجففة جزئيا و المغلفة بالاغشيه الطبيعيه}

\section{مصطفى طه محمدى عسوس}

\section{معرج بحوث تكنولوجيا الأغذية ، مركز البحوث الزراعية ، الجيزة، مصر}

أجريت هذه الدراسة بغرض انتاج وتقييم شرائح المانجو المعامله أسموزيا أو المجفهه جزئيا بالهواء الساخن بعد الاسموزية ثم تغطيتها بالاغشية الطبيعية (الثيتوزان) . وتم دراسة تأثثر ذلك

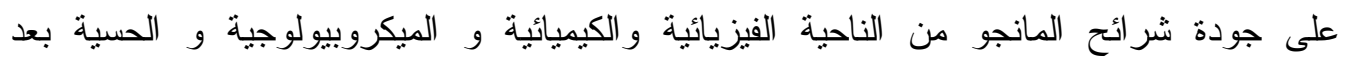

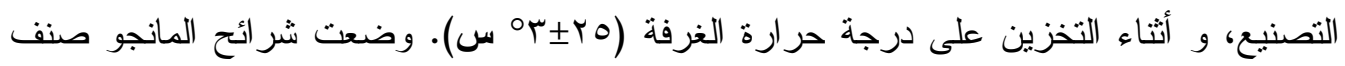

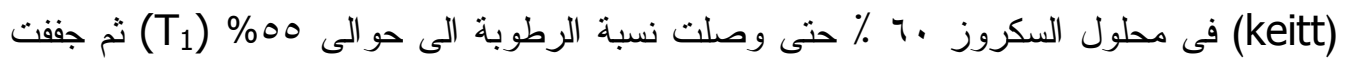

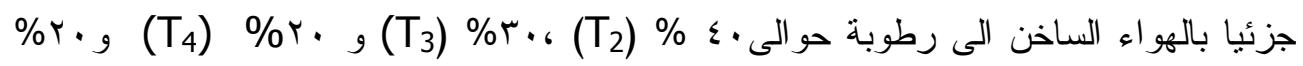

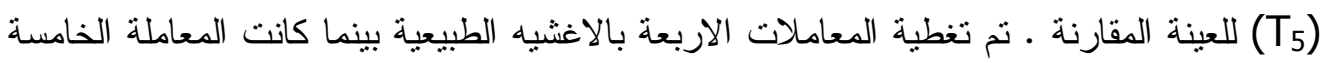

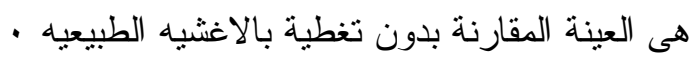

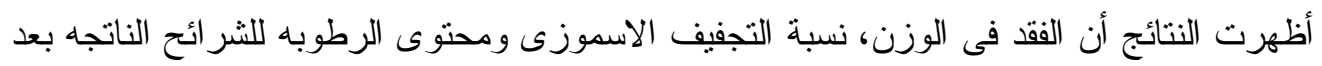

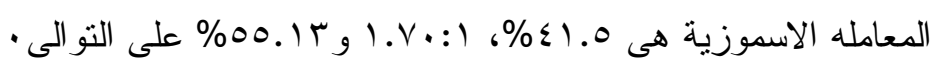

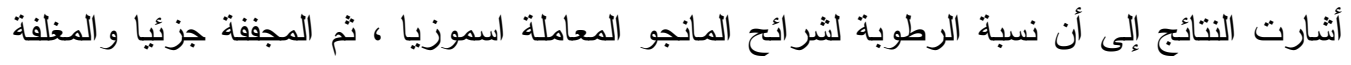

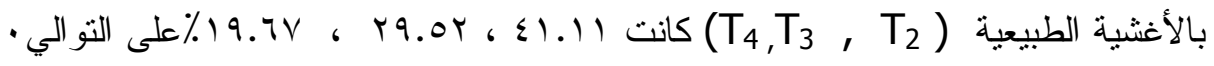
أظهرت النتائج المحافظة على الخصائص الفيزيائية والكيميائية للمعاملات المعاملة اسموزيا و المجففة بالهو اء الساخن و المغلفة بالاغثية الطبيعية اثثاء فتزة التخزين مقارنة بالعينة المقارنة ـ كما ولائه

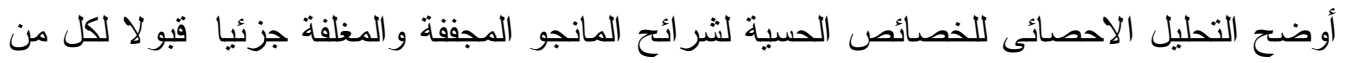

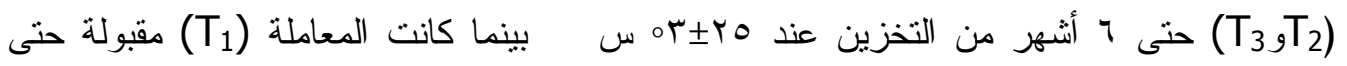

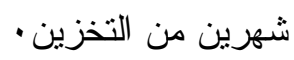
لم ير افق تغليف شر ائح المانجو و المعاملة أسموزيا او المعاملة أسموزيا و المجففة جزيئا بالهواء الساخن بالأغشية الطبيعية ( الثيتوز ان -ميثايل سيليلوز) زيادة ملحوظة في الحمل الميكروبى اثثاء 